\title{
Co-production of electricity, heat and biocoal pellets from biomass: a techno-economic comparison with wood pelletizing
}

\author{
Berit Erlach*, Benjamin Wirth, George Tsatsaronis \\ Technische Universität Berlin, Institute for Energy Engineering, Berlin, Germany \\ * Corresponding author. Tel: +49 30 31428449, Fax: +49 30 31428613, E-mail: erlach@iet.tu-berlin.de
}

\begin{abstract}
Hydrothermal carbonization (HTC) is an artificial coalification process which converts raw biomass into a coal-like product, biocoal. Biocoal has a higher energy density than the original biomass and is easier to transport, store and process. Hence, HTC is recently promoted as an upgrading technology, especially for wet biomass. For HTC to become a commercial technology, it is essential to identify applications which offer technical or economic advantages over conventional biomass processes. This paper presents a process design where HTC is integrated with wood-fired combined heat and power production (HTC-CHP), and compares it to standalone HTC (HTC-sep) and to wood pelletizing integrated with CHP (WP-CHP). The respective plant designs are modeled with Aspen Plus and an economic analysis is performed using investment costs from literature. The overall efficiency of electricity, heat and wood or biocoal pellet production is very close in all considered cases. When biodegradable waste is available at zero cost, the production costs of biocoal pellets are similar to those of wood pellets. If wood chips are used as an HTC feedstock, the production costs are $32-38 \%$ higher. The average cost of $\mathrm{CO}_{2}$ avoidance is highest for the standalone HTC plant, due to the auxiliary consumption of natural gas and electricity.
\end{abstract}

Keywords: hydrothermal carbonization, biocoal, biomass, wood pellets

\section{Introduction}

Co-firing with coal has been identified as one of the least expensive and most efficient technologies for converting biomass to electricity [1]. This gives rise to a demand for biofuels with a uniform quality and high energy density, which can be processed in the fuel handling and combustion equipment of existing coal-fired power plants. Since most raw biomass falls short of these requirements, upgrading technologies, which improve the properties of biomass for transport, storage, combustion and gasification, have become of interest. The most established upgrading technology today is wood pelletizing, whereby wood is dried, milled and pressed into pellets of a defined form and size. Several technologies which convert biomass into a more coal-like product through chemical processing are currently being developed, but not yet commercialized. While torrefaction and fast pyrolysis have been mainly applied to dry wood and straw, hydrothermal carbonization (HTC) does not require prior drying and has been successfully tested with a wide range of biomass including wood, straw, cut grass, municipal waste, digestate, and bark mulch in laboratory scale experiments $[2,3]$.

To achieve a high overall energetic efficiency of 80 to $90 \%$ (HHV basis), efficient heat recovery within an HTC plant is required [4]. However, complex heat recovery might not be attractive due to operability issues and cost. This paper presents a process design in which the need for a complex heat recovery design within the HTC process is eliminated by integrating the HTC process with wood-fired combined heat and power production (CHP). Steam for the HTC reactor is bled from a steam turbine extraction, while low temperature heat from the cooling of the HTC reaction products is used for district heating and for combustion air and water preheating for the CHP process. This integrated design is compared to a stand-alone HTC plant and to wood pelletizing, also integrated with $\mathrm{CHP}$, in relation to energetic efficiency and production costs. Poplar wood chips from short rotation coppice and biodegradable waste are considered as feedstocks for the HTC process. 


\section{Hydrothermal carbonization as an upgrading technology for biomass}

HTC is an artificial coalification process which takes place in pressurized water at 200 to $250^{\circ} \mathrm{C}$ at or above saturation pressure and is slightly exothermic. Oxygen is removed from the feedstock through the formation of water and $\mathrm{CO}_{2}$, thereby increasing the carbon content and higher heating value (HHV). HTC renders gaseous and dissolved byproducts containing $\mathrm{CO}_{2}$, carbon monoxide, organic acids, phenol, furfural and hydroxymethylfurfural [5,6]. Minerals contained in the biomass are partly dissolved in the aqueous phase [7]. By destroying the cell structure of the biomass and removing oxygen-containing functional groups, HTC makes the product hydrophobic [8] and facilitates mechanical dewatering, which is much less energy intensive than thermal drying. Previous simulation studies show that for fresh wood with 50 to $60 \%$ moisture (wet basis), pre-treatment with HTC before combustion could increase the overall energetic efficiency compared to the combustion of the untreated wood by 5 to 12 percentage points, given that dissolved organics losses are limited to 5\% (by weight) and that mechanical dewatering yields $70 \%$ dry matter content [4]. In laboratory scale dewatering experiments, a dry matter content of 57 to $68 \%$ was achieved for biocoal from biodegradable waste [9].

Fig. 1 presents a flow diagram for a continuous HTC plant. The heat recovery scheme is adopted from a pilot plant for the hydrothermal treatment of peat [10]. The biomass is mixed with recycled process water to create a pumpable slurry, and then preheated in several stages by mixing with steam recovered at different temperature levels from the product depressurizing. Only direct heat exchange is employed at temperatures greater than $100^{\circ} \mathrm{C}$ because (carbonized) peat slurry was found to cause fouling and clogging problems within heat exchangers [11]. The additional steam required to reach the reaction temperature is produced by a natural gas boiler. The product is mechanically dewatered, dried to a moisture content of $10 \%$ (w.b.) and pelletized. Low temperature drying uses steam at $100^{\circ} \mathrm{C}$ to heat up the drying air. The gaseous byproducts from the HTC reactor are co-combusted in the natural gas boiler. We described a similar plant design in detail in [4].

The need for a complex heat recovery scheme within the HTC process can be eliminated by integrating the HTC process with a CHP plant using wood chips as a fuel, as shown in Fig. 2. Steam for the HTC reactor is taken from the steam turbine. The biocoal slurry is depressurized in two steps. Some of the recovered steam is used to preheat the biomass slurry to $90^{\circ} \mathrm{C}$ and to supply the biocoal dryer. The remainder of the steam, plus heat from the waste water, gaseous byproducts and biocoal slurry cooling are used to generate steam at $0.2 \mathrm{MPa}$ for the deaerator, for the combustion air and make-up water preheating, and for district heat production.

\section{Methodology}

The standalone HTC plant (HTC-sep) and the integrated plant design (HTC-CHP) described above are modeled with Aspen Plus V7.1, a simulation package which calculates material and energy balances for a given flowsheet of a steady-state chemical process. A stand-alone CHP plant (CHP-sep) and a CHP plant integrated with wood pelletizing (WP-CHP) are also modeled for comparison. The design of CHP-sep and WP-CHP corresponds to the integrated CHP process (marked by grey underlay in Fig. 2), without flow streams A, B, G, F, and H. In $W P-C H P$, additional steam is extracted at $0.12 \mathrm{MPa}$ for drying the wood to a water content of $10 \%$ before milling and pelletizing. Based on the simulation results, raw material and auxiliary energy demand are obtained, and plant equipment is sized. Investment costs for the plant equipment are estimated, and the annual levelized product costs are calculated for each 
simulation case. Poplar chips from short rotation coppice with a water content of $50 \%$ (w.b.) are used as a fuel for the CHP plant and as the raw material for the HTC and wood pelletizing. For the HTC-CHP, a s econd case is analyzed, with biodegradable waste as the HTC feedstock. All HTC simulation cases have an input of $11.15 \mathrm{MW}_{\mathrm{HHV}}$, requiring either $4 \mathrm{t} / \mathrm{h}$ wood or $8.6 \mathrm{t} / \mathrm{h}$ biodegradable waste.

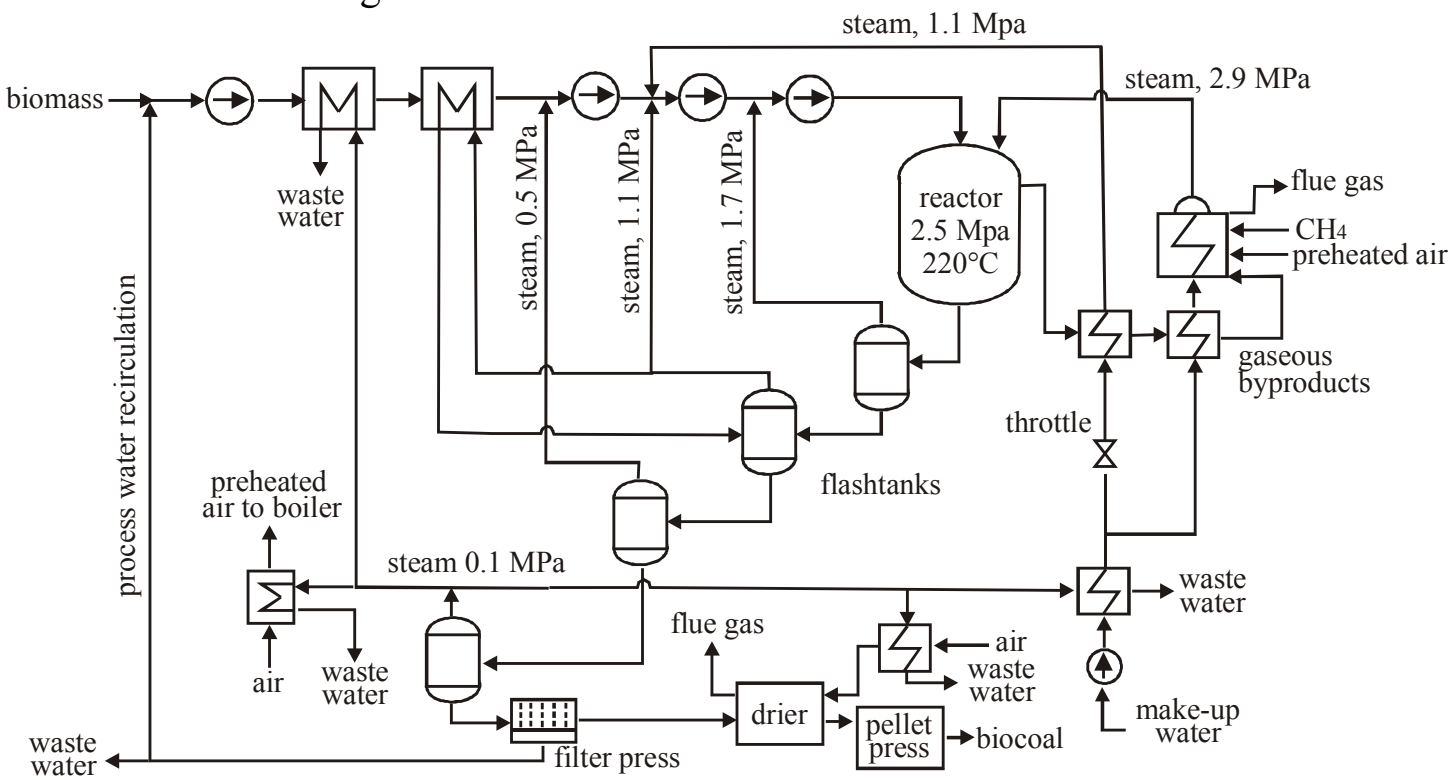

Fig. 1. Flow diagram of a stand-alone HTC plant (HTC-sep) with staged heat recovery.

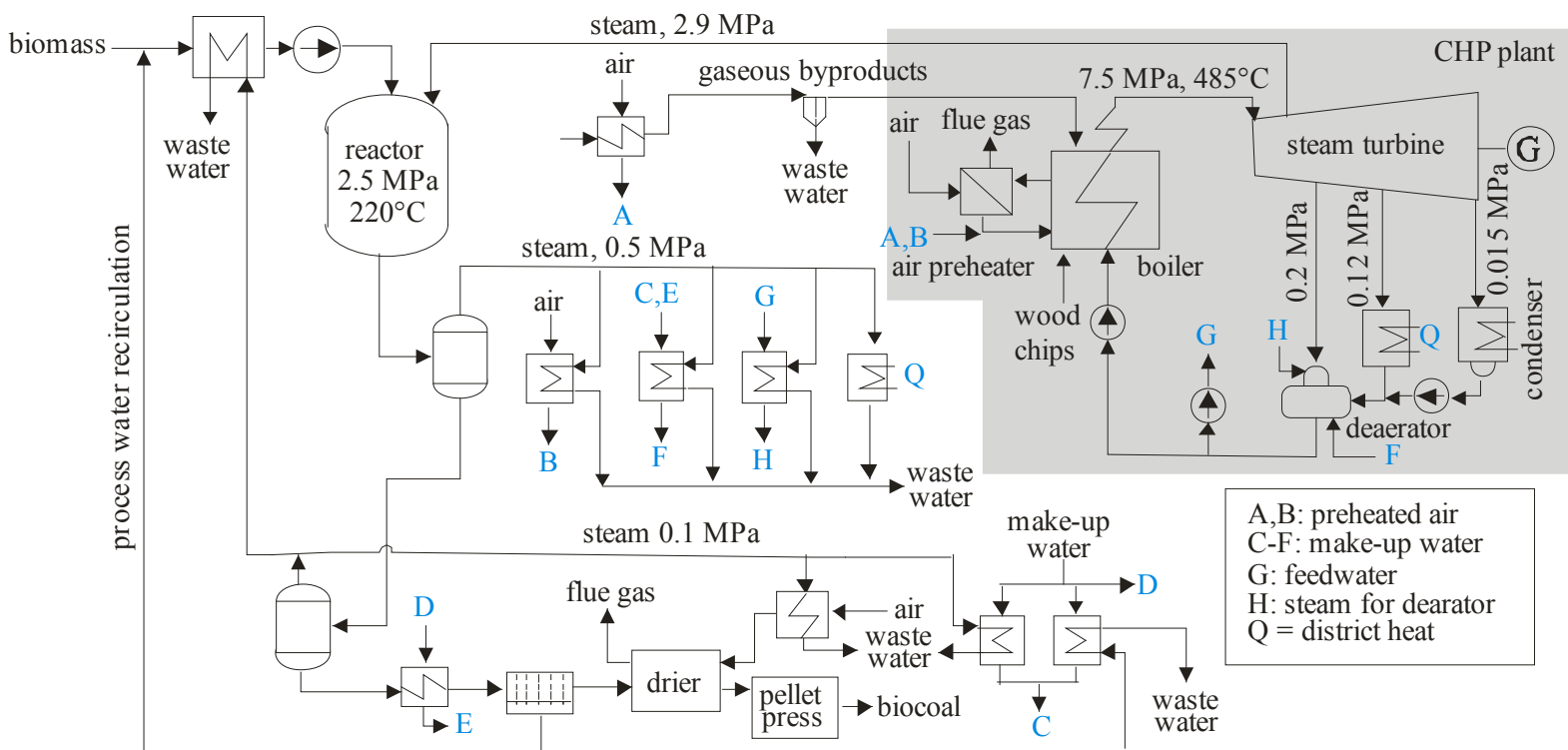

Fig. 2. Flow diagram of an integrated HTC and CHP plant (HTC-CHP).

\subsection{Modelling assumptions}

The operation of each plant is simulated for an average day within and outside the heating season, a cold winter day of $-10^{\circ} \mathrm{C}$ with maximum heat load and frozen biomass, and a hot summer day of $30^{\circ} \mathrm{C}$. The district heat load is taken to be $1.0 \mathrm{MW}$ outside the heating season, 15.7 MW on the average winter day and 20.7 MW at capacity. Outside the heating season, the boiler runs at approximately $40 \%$ capacity, and the steam not used for district heating (7.0 $\mathrm{MW}$ ) is discharged to the condenser. For the biomass upgrading processes, an availability of $80 \%$ is assumed, due to maintenance requirements and fluctuation in biomass supply. 
The HTC reactor is modeled as a black box, with yields and composition of the biocoal and byproducts based on experimental data using poplar wood and straw at $220^{\circ} \mathrm{C}$ with a residency time of 4 hours [12] and on published data [13]. The composition (wt\%, d.b.) of biomass and biocoal is given in Table 1. Mass yields (d.b.) are $70.3 \%$ to $70.9 \%$ for the biocoal from wood and $71.9 \%$ for the biocoal from waste. Dissolved organic byproducts account for $10.1 \%$ of the feedstock dry mass. The solid matter content is assumed to be $15 \%$ at the slurry pump inlet and $60 \%$ after mechanical dewatering with a filter press. Since biocoal is brittle, it is assumed that it can be fed directly to the pellet press without prior milling.

Table 1. Characteristics of wood, biodegradable waste, biocoal and dissolved organics.

\begin{tabular}{lrrrrr}
\hline & \multicolumn{1}{c}{ wood } & \multicolumn{1}{c}{ waste } & \multicolumn{1}{c}{$\begin{array}{l}\text { biocoal } \\
\text { (wood) }\end{array}$} & $\begin{array}{l}\text { biocoal } \\
\text { (waste) }\end{array}$ & $\begin{array}{r}\text { dissolved } \\
\text { organics }\end{array}$ \\
\hline Carbon & $49.75 \%$ & $38.60 \%$ & $63.68 \%$ & $48.54 \%$ & $40.52 \%$ \\
Hydrogen & $6.08 \%$ & $5.30 \%$ & $5.65 \%$ & $4.27 \%$ & $5.36 \%$ \\
Oxygen & $42.85 \%$ & $36.10 \%$ & $29.47 \%$ & $21.96 \%$ & $54.12 \%$ \\
Ash & $1.32 \%$ & $20.00 \%$ & $1.21 \%$ & $25.23 \%$ & - \\
HHV (d.b.) (MJ/kg) & 20.07 & 15.58 & 25.81 & 19.18 & - \\
Water content (w.b.) & $50 \%$ & $70 \%$ & $10 \%$ & $10 \%$ & - \\
\hline
\end{tabular}

\subsection{Economic analysis}

Module costs for the plant equipment are estimated based on vendors data (for the wood pelletizing equipment) and literature. For the biomass upgrading processes, overdesign (safety) factors of $10-20 \%$ are applied. All components in contact with the biomass or biocoal slurry are stainless steel. Costs are converted to $2009 €$. The total capital investment (TCI) comprises the total module costs plus fees and contingencies (15\% of module costs), offsite costs (land, ancillary buildings, site development, utilities), working capital and start-up costs. The investment annuity is calculated with an economic plant life of 15 years and an interest rate of $7.0 \%$ p.a. Constant money values are used with real escalation rates of $0.5 \%$ p.a. for natural gas and purchased electricity, and $0.3 \%$ p.a. for wood chips and bituminous coal. Annual levelized costs for auxiliary energy, raw materials, and operation and maintenance are calculated with the constant escalation levelization factor (CELF).

The costs for the wood chips from short rotation coppice are calculated including cultivation and harvest, transportation and seasonal storage. It is assumed that the standalone HTC-plant is located in the centre of the cultivation area and that wood chips are stored onsite. The transport distance is calculated relative to the biomass demand under the assumption that $10 \%$ of the surrounding area is used to grow short rotation coppice. The location for the CHP plant would be selected based on district heat demand rather than biomass supply, and the seasonal storage of biomass has to be off-site. Therefore, an additional truck reload and transport of $100 \mathrm{~km}$ are assumed in this case. Biodegradable waste is assumed to be available at zero cost, including delivery to the HTC plant.

The total annual levelized revenue requirement (TRR) in $€ /$ a of the HTC-CHP plant equals the production costs of the three products, namely electricity, district heat and biocoal pellets. Assuming that specific revenues for district heat and electricity are the same for all plant designs, the specific cost of the biocoal pellets $\left(c_{\text {pellets }}\right)$ in $€ / G J$ can be calculated according to Eq. (1), where $W$ is the net annual electricity production in GJ/a, $c_{w}$ the renumeration for electricity feed-in from the CHP plant in $€ / G J$, and $Q_{\text {pellets }}$ is the annual pellet production in GJ/a. The specific costs of wood pellets in WP-CHP are calculated in the same way. 
$c_{\text {pellets }} Q_{\text {pellets }}=\left(T R R_{H T C-C H P}-T R R_{C H P-s e p}\right)-c_{w}\left(W_{H T C-C H P}-W_{C H P-s e p}\right)$

The cost of $\mathrm{CO}_{2}$ avoidance is calculated with Eq. (2), assuming that the upgraded biofuel substitutes bituminous coal, that no additional investment at the power plant is required and that efficiency is not affected. $c_{\text {pellets,LHV }}$ and $c_{\text {bit.coal } L H V}$ are the specific costs in $€ / \mathrm{GJ}_{\mathrm{LHV}}$, and $e_{\text {pellets }}$ and $e_{\text {bit.coal }}$ the specific emissions in $\mathrm{t}_{2}$ per $\mathrm{GJ}_{\mathrm{LHV}}$ for the respective fuels.

$c_{C O 2}=\frac{C_{\text {pellets }, \mathrm{LHV}}-C_{\text {bit.coal }, \mathrm{LHV}}}{e_{\text {bit.coal }}-e_{\text {pellets }}}$

\section{Results}

In the following, the standalone HTC and CHP plants, HTC-sep and CHP-sep, are treated as one system with two separately located plants for the purpose of the economic analysis, in order to better identify the effects of the integration.

\subsection{Technical performance}

Low ambient temperatures lead to a higher energy demand for preheating the drier air and the biomass. At $5^{\circ} \mathrm{C}$, the natural gas demand in $H T C$-sep is $13 \%$ higher than at $15^{\circ} \mathrm{C}$, at $-10^{\circ} \mathrm{C}$ with frozen biomass it is $50 \%$ higher. At $+30^{\circ} \mathrm{C}$, a surplus of heat $(191 \mathrm{~kW})$ has to be discharged to the environment, for which coolers are required. Annual energy balances for the analyzed cases are given in Table 2. The overall efficiency on an HHV (LHV) basis of HTCsep is $81.1 \%(92.9 \%)$. The electrical efficiency of CHP-sep is $16.3 \%(20.1 \%)$, and the energetic efficiency $53.4 \%(65.8 \%)$. The overall energetic efficiency, where the sum of biofuel energy (HHV), net electricity and district heat is the product and the raw biomass is the fuel, is very close in all considered cases - it ranges from $60.8 \%$ when biocoal is produced from wood to $59.7 \%$ when biocoal is produced from waste.

Table 2. Annual energy balances (on HHV basis).

\begin{tabular}{llrrrrrr}
\hline & & $\begin{array}{l}\text { HTC- } \\
\text { sep }\end{array}$ & $\begin{array}{l}\text { CHP- } \\
\text { sep }\end{array}$ & $\begin{array}{l}\text { HTC-CHP } \\
\text { wood }\end{array}$ & $\begin{array}{l}\text { HTC-CHP } \\
\text { waste }\end{array}$ & WP-CHP \\
\hline Inputs & & & & & & & \\
Biomass (upgrading) & $(\mathrm{GWh} / \mathrm{a})$ & 75.14 & - & 75.14 & 75.14 & 75.14 \\
Biomass (combustion) & $(\mathrm{GWh} / \mathrm{a})$ & - & 224.65 & 232.60 & 233.88 & 255.17 \\
Natural gas & $(\mathrm{GWh} / \mathrm{a})$ & 7.68 & - & - & - & - \\
Net electricity consumption & $(\mathrm{GWh} / \mathrm{a})$ & 1.16 & - & - & - & - \\
\hline Products & & & & & & & \\
Net electricity Production & $(\mathrm{GWh} / \mathrm{a})$ & - & 36.69 & 35.47 & 34.60 & 39.51 \\
District heat & $(\mathrm{GWh} / \mathrm{a})$ & - & 83.33 & 83.33 & 83.33 & 83.33 \\
Upgraded biofuel & $(\mathrm{GWh} / \mathrm{a})$ & 67.72 & - & 68.24 & 66.54 & 75.14 \\
\hline
\end{tabular}

The HTC process receives $21.7 \mathrm{GWh} / \mathrm{a}$ from the CHP plant, of which $75 \%$ is returned at a lower temperature level, resulting in a net import of $5.4 \mathrm{GWh} / \mathrm{a}$. This leads to an increased demand for boiler fuel wood chips for $H T C$-CHP compared to $C H P$-sep. Using biodegradable waste instead of wood for the HTC increases the steam flow by $14 \%$. The wood pelletizing requires $15.7 \mathrm{GWh} / \mathrm{a}$ of steam, resulting in a $10 \%$ higher consumption of boiler fuel wood chips compared to HTC-CHP. Since the turbine extraction in WP-CHP is at a lower pressure, 
additional electricity is produced in co-generation. The yield of upgraded biofuel is higher for WP-CHP, since in the HTC reaction, part of the biomass is converted to heat and byproducts.

\subsection{Economic analysis}

Wood chip costs including transport and storage result in $3.86 € / G \mathrm{~J}$ for HTC-sep, with a land requirement of $1710 \mathrm{ha}$ of short rotation coppice and an average transport distance of $9 \mathrm{~km}$. For CHP-sep, HTC-CHP and WP-CHP, wood chips costs are 4.48 to $4.50 € / \mathrm{GJ}$, due to the larger catchment area, and additional transport from the seasonal storage site to the plant.

Table 3. Economic results.

\begin{tabular}{|c|c|c|c|c|c|}
\hline & & $\begin{array}{l}\text { HTC-sep, } \\
\text { CHP-sep }\end{array}$ & $\begin{array}{l}\text { HTC-CHP } \\
\text { wood }\end{array}$ & $\begin{array}{l}\text { HTC-CHP } \\
\text { Waste }\end{array}$ & $\begin{array}{l}\text { WP- } \\
\text { CHP }\end{array}$ \\
\hline \multicolumn{6}{|l|}{ Investment costs } \\
\hline HTC reactor & $(\mathrm{k} €)$ & 1206 & 1133 & 1176 & 0 \\
\hline Slurry pumps, flash tanks, screw feeder & $(\mathrm{k} €)$ & 754 & 460 & 491 & 0 \\
\hline Filter press & $(\mathrm{k} €)$ & 846 & 799 & 951 & 0 \\
\hline Drying, milling, pelletizing & $(\mathrm{k} €)$ & 1496 & 1495 & 1728 & 2595 \\
\hline Heat exchangers, product coolers & $(\mathrm{k} €)$ & 740 & 735 & 825 & 0 \\
\hline Auxiliary boiler & $(\mathrm{k} €)$ & 141 & 0 & 0 & 0 \\
\hline Waste water treatment & $(\mathrm{k} €)$ & 245 & 288 & 419 & 0 \\
\hline Biomass sizing, metal/plastic screening & $(\mathrm{k} €)$ & 0 & 0 & 218 & 0 \\
\hline Upgrading plant, total module costs & $(\mathrm{k} €)$ & 5427 & 4910 & 5807 & 2595 \\
\hline CHP plant module costs & $(\mathrm{k} €)$ & 17313 & 17717 & 17674 & 18633 \\
\hline Total capital requirement (TCI) & $(\mathrm{k} €)$ & 30819 & 30600 & 31586 & 28733 \\
\hline \multicolumn{6}{|l|}{ Levelized costs } \\
\hline Carrying charges ${ }^{1)}$ & $(\mathrm{k} € / \mathrm{a})$ & 3698 & 3672 & 3789 & 3448 \\
\hline Operation \& maintenance ${ }^{2)}$ & $(\mathrm{k} € / \mathrm{a})$ & 1733 & 1517 & 1720 & 1145 \\
\hline Wood chips & $(\mathrm{k} € / \mathrm{a})$ & 4763 & 5077 & 3858 & 5449 \\
\hline Electricity and natural gas ${ }^{3)}$ & $(\mathrm{k} € / \mathrm{a})$ & 276 & 0 & 0 & 0 \\
\hline Total revenue requirement & $(\mathrm{k} € / \mathrm{a})$ & 10470 & 10265 & 9367 & 10041 \\
\hline Revenues electricity ${ }^{3)}$ & $(\mathrm{k} € / \mathrm{a})$ & 2936 & 2837 & 2768 & 3161 \\
\hline Revenues district heat ${ }^{4)}$ & $(\mathrm{k} € / \mathrm{a})$ & 4248 & 4249 & 4248 & 4248 \\
\hline Production cost upgraded biomass & $(\mathrm{k} € / \mathrm{a})$ & 3286 & 3178 & 2351 & 2632 \\
\hline Specific cost upgraded biomass & $\left(€ / \mathrm{GJ}_{\mathrm{HHV}}\right)$ & 13.48 & 12.94 & 9.81 & 9.73 \\
\hline Specific cost upgraded biomass & $\left(€ / \mathrm{GJ}_{\mathrm{LHV}}\right)$ & 14.32 & 13.74 & 10.47 & 10.57 \\
\hline $\mathrm{CO}_{2}$ avoidance cost ${ }^{5)}$ & $\left(€ / \mathrm{tCO}_{2}\right)$ & 135.14 & 115.75 & 81.28 & 82.36 \\
\hline \multicolumn{6}{|l|}{ 1) Annuity plus tax and insurances ( $1 \%$ of TCI) } \\
\hline \multicolumn{6}{|c|}{$\begin{array}{l}\text { 2) Operating labour requirement estimated based on plant equipment. Plant operators: } 27.63 € / \mathrm{h} \text {, biomass yard } \\
\text { workers: } 20.75 € / \mathrm{h} \text {. Material costs: } 10 \% \text { of module costs for high wear components, } 2 \% \text { for other components. } \\
{ }^{3)} \text { Energy prices: natural gas: } 6.31 € / \mathrm{GJ}_{\mathrm{HHV}} \text {, purchased electricity: } 22.22 € / \mathrm{GJ} \text {, electricity revenues: } 22.22 € / \mathrm{GJ} \\
{ }^{4)} \text { Calculated from CHP-sep }\end{array}$} \\
\hline
\end{tabular}

The results of the economic analysis are shown in Table 3. The equipment costs for HTC are about twice than that for wood pelletizing. The higher complexity of the HTC plant compared to wood pelletizing also leads to a higher labour requirement and operation and maintenance costs. The integrated plant design saves $10 \%$ on the equipment cost for HTC, mostly related to biomass pressurizing, flash tanks, heat exchangers and the omission of the auxiliary boiler. However, this is offset by higher investment in the CHP plant, which needs a higher capacity due to the additional steam production. The investment for HTC utilizing biodegradable waste 
is $18 \%$ higher than that for the plant using wood, due to higher biomass and biocoal mass flows and additional metal and plastic contaminant screening equipment.

Product costs of the upgraded biomass range from $9.73 € / \mathrm{GJ}(175.7 € / \mathrm{t})$ for wood pellets to $13.48 € / G J$ for biocoal produced in the standalone HTC plant. Despite the higher cost of wood chips due to transportation logistics, integration with the CHP plant leads to a slight decrease in biocoal cost. Biocoal pellets produced from biodegradable waste are comparable to wood pellets, assuming zero cost for the biodegradable waste. The cost for $\mathrm{CO}_{2}$ avoidance when the biofuel is used to substitute bituminous coal is lowest for the biocoal from waste. For HTCsep, only $90 \%$ of the $\mathrm{CO}_{2}$ is avoided due to consumption of natural gas and electricity from the grid, while in the integrated cases, the HTC energy requirements are completely covered by biomass, resulting in zero direct emissions (supply chain emissions aside). The product costs are strongly dependent on the cost of the biomass, which contributes $32 \%$ of the annual cost in HTC-sep, and around 50\% for the integrated plants.

\section{Further technical considerations}

While wood pelletizing is an established technology, there remains significant uncertainty about some technical aspects and the economics of the HTC plant, because there are no commercial-scale HTC plants yet in operation. Data for the HTC reaction is currently based on laboratory-scale batch experiments. Optimization of the design and operating parameters of the HTC plant might yield higher efficiencies. Key technical issues include biomass pressurizing and the dissolved organics. The dissolved organics result in a substantial energy loss and require waste water treatment. However, the quantity and composition of dissolved organics from laboratory scale experiments may not be representative for a continuous HTC process with process water reflux. In the analyzed plant designs, 21600 to $68400 \mathrm{~m}^{3}$ per year of waste water are generated. That said, experiments on aerobic and anaerobic degradation are reported to indicate good degradability [9]. Low-boiling organics might evaporate in the drier and necessitate remedial treatment of the drier exhaust for VOC emissions.

Regarding product quality, biocoal pellets from wood have a higher calorific value than wood pellets. Biocoal pellets from biodegradable waste are likely to have a higher ash content, resulting in a lower calorific value. The quantity and composition of mineral matter in the biocoal is a consideration for combustion applications. In particular, ash melting temperature, flue gas cleaning requirements and corrosion need to be examined in greater detail. If biocoal is co-fired with coal, sulfur in the biocoal should not be an issue, since coal-fired power plants are equipped with desulfurization. However, the gaseous phase from the HTC of biodegradable waste was found to contain significant amounts of $\mathrm{H}_{2} \mathrm{~S}$ [13], which could prove more problematic. For biocoal to become a commodity fuel, quality standards regarding ash, sulfur and heavy metal content need to be developed and implemented to avoid damage to combustion equipment and the environment.

\section{Conclusions}

Hydrothermal carbonization (HTC) is an artificial coalification process which is being promoted as an upgrading technology for high moisture biomass. Under the economic assumptions made in this paper, biocoal pellets from biodegradable waste can be produced at a cost of $9.8 € / \mathrm{GJ}_{\mathrm{HHV}}$ when the waste is available at zero cost. This is comparable to the cost of wood pellets. The economics of HTC from biodegradable waste would be further improved if the HTC operator is paid for the disposal of the waste. When wood chips are used as a feedstock for HTC, the pellet costs are 30\% higher. This raises the question whether the 
application of HTC can be justified for biomass that can be easily pelletized without further pretreatment. Since the biocoal pellets produced by HTC are closer to coal, they might be better suited than wood pellets for co-firing in existing coal-fired power plants. Regarding plant design, integrating HTC with a CHP-plant eliminates the need for a complex heat recovery scheme within the HTC-plant and thereby aids operability. The modeling in this paper relied on laboratory scale data and simulation. Operational data from HTC pilot plants is needed to reduce uncertainty regarding conversion efficiency, availability and investment costs.

Acknowledgements: This work has been funded by the German Federal Ministry of Education and Research as part of the joint research project 01LS0806B.

\section{References}

[1] L. Baxter, Biomass-coal co-combustion: opportunity for affordable renewable energy. Fuel 84, 2005, pp. 1295-1302.

[2] C. Grimm, Fördervorhaben der DBU zur Hydrothermalen Karbonisierung - Ziele und Stand. Gülzower Fachgespräche 33, F achagentur Nachwachsende Rohstoffe (FNR), 2010, pp. 33-41.

[3] A. Funke, F. Ziegler, Hydrothermal Carbonization of Biomass: A Literature Survey Focussing on i ts Technical Application and Prospects, Proc. 17th European Biomass Conference \& Exhibition, 2009, Florence, Italy, and Munich, Germany, pp. 1037-1050.

[4] B. Erlach, G. Tsatsaronis, Upgrading of biomass by hydrothermal carbonisation: Analysis of an industrial-scale plant design. Proc. ECOS - 23rd International Conference. Jun 1417, 2010, Lausanne, Switzerland.

[5] F. Bergius, Beiträge zur Theorie der Kohleentstehung, Die Naturwissenschaften, 16 (1), 1928, pp. 1-10.

[6] M. Gerhardt, M. Berg, B. Kamm, Hydrothermal carbonization of lignocellulosic biomass and its precursors. Proc. International Conference on Polygeneration Strategies with special Focus on Integrated Biorefineries, Sep 07-09, 2010, Leipzig, Germany.

[7] J. Pels, P. Bergman, TORWASH. Proof of Principle. Phase 1, Technical Report, ECN-E06-021, Energy research Centre of the Netherlands (ECN), 2006, Petten.

[8] W. Yan, et al., Thermal Pretreatment of Lignocellullosic Biomass, Environmental Progress \& Sustainable Energy 28 (3), 2009, pp. 435-440.

[9] H. Ramke, Hydrothermale Carbonisierung organischer Siedlungsabfälle, 22. Abfallwirtschaftsforum, Gießen, 2010.

[10]M. Mensinger, Wet Carbonization of Peat: State-of-the-Art Review, Symposium Proceedings: Peat as an Energy Alternative. IGT, 1980, Chicago, Ill., pp. 249-280.

[11]S. Hägglund, (ed.), Vatkolning av Torv AB. Svensk Torvförädling, Lund, Sweden, 1960.

[12]M. Gerhardt, S. Kieseler, pers. comm. [experiments conducted at Technische Universität Berlin and Forschungsinstitut Bioaktive Polymersysteme, Berlin], Jun-Nov 2010.

[13]K. Serfass, Hydrothermale Carbonisierung. Eignung und Verarbeitung unterschiedlicher Biomassen zu Biokohle. Presentation at C.A.R.M.E.N Statusseminar Hydrothermale Karbonisierung (HTC), Aschaffenburg, Okt 5, 2010. 